\title{
Hyperuricemia in Patients with Chronic Renal Failure in the General Hospital of National Reference of N'Djamena (Chad)
}

\author{
Guillaume Mahamat Abderraman ${ }^{1}$, Ibrahim Hamat' ${ }^{1}$ Zeinabou Maiga Moussa Tondi'2, \\ Ahmed Tall Lemrabott ${ }^{3}$, Maria Faye ${ }^{3}$, Cisse Mouhamadou Moustapha ${ }^{3}$, Kossi Akomola Sabi ${ }^{4}$, \\ Ka Elhaj Fary $\mathrm{Ka}^{3}$, Niang Abdou ${ }^{3}$, Diouf Boucar ${ }^{3}$ \\ ${ }^{1}$ Hemodialysis Unit, Hôpital Général de Référence Nationale (HGRN), N’Djamena, Tchad \\ ${ }^{2}$ Medical Department, FSS/ Université Abdou Moumouni de Niamey, Service de Néphrologie et Hémodialyse, Hôpital National \\ Lamordé de Niamey, Niamey, Niger \\ ${ }^{3}$ Nephrology service, Hôpital Aristide Le Dantec de Dakar, Dakar, Sénégal \\ ${ }^{4}$ Nephrology and Hemodialysis Service, CHU SO Lomé, Lomé, Togo \\ Email: *zalba2001@yahoo.fr
}

How to cite this paper: Mahamat Abderraman, G., Hamat, I., Tondi, Z.M.M., Lemrabott, A.T., Faye, M., Moustapha, C.M., Sabi, K.A., Ka, K.E.F., Abdou, N. and Boucar, D. (2017) Hyperuricemia in Patients with Chronic Renal Failure in the General Hospital of National Reference of N'Djamena (Chad). Open Journal of Nephrology, 7, 918.

https://doi.org/10.4236/ojneph.2017.71002

Received: November 25, 2016

Accepted: January 21, 2017

Published: January 24, 2017

Copyright $\odot 2017$ by authors and Scientific Research Publishing Inc. This work is licensed under the Creative Commons Attribution International License (CC BY 4.0).

http://creativecommons.org/licenses/by/4.0/ (c) (i) Open Access

\begin{abstract}
Introduction: Hyperuricemia is defined as a level of serum uric acid greater than or equal to $70 \mathrm{mg} / \mathrm{l}(420 \mu \mathrm{mol} / \mathrm{l})$ in men and $60 \mathrm{mg} / \mathrm{l}(360 \mu \mathrm{mol} / \mathrm{l})$ in women. Several studies have shown that it is a risk factor or a factor of progression of chronic kidney disease. Recent experimental and epidemiological data correlate the association of hyperuricemia with chronic kidney disease (CKD), arterial hypertension and cardiovascular diseases, thus raising the question of the usefulness of therapeutics in the prevention of renal diseases. The objective of this study is to seek a link between chronic kidney disease and hyperuricemia. Materials and Methods: This is a descriptive and analytical study conducted at hemodialysis unit and cardiology service of General Hospital of National reference of N'Djamena (Chad) from $1^{\text {th }}$ January to $1^{\text {th }}$ October 2013 (10 months). We included all chronic kidney disease patients hospitalized in hemodialysis unit and cardiology service who presented associated hyperuricemia. Results: There were 712 CKD patients who were hospitalized. Among them, there were 108 patients who were included in the study and who had hyperuricemia as a prevalence of $15.20 \%$. The average age of patients was 35.5 years and the sex ratio was $3 / 1$. The age group between 40 to 60 years represented $54.6 \%$. There were $41.7 \%$ of traders. Hypertensive patients accounted for 49.1\%; association of diabetes and hypertension was noted in $12.90 \%$. Renal insufficiency was moderate in $43.5 \%$ of patients. Hyperuricemia was present in more than $90 \%$ of patients. Profession, age, hematuria, proteinuria and hypertension were statistically positively related to
\end{abstract}


hyperuricemia. Treatment consisted of prescribing allopurinol in $84 \%$ of patients. In more than $11 \%$ of patients the progression was unfavorable. Conclusion: The implication of hyperuricemia in chronic kidney disease has been proved in several recent studies. However, randomized studies at very long scales have to be carried out to conclude from its real impact on the prevention and treatment of chronic kidney disease.

\section{Keywords}

Component, Formatting, Style, Styling

\section{Introduction}

Chronic kidney disease (CKD) is a major public health problem in the world [1]. Indeed, it is the twelfth cause of death and the seventeenth cause of disability in the world [2]. Its prevalence and incidence have increased significantly in recent years worldwide [3]. In sub-Saharan Africa, the CKD mainly affects young adults in their productive age and is a significant cause of death reducing life expectancy [3] [4] [5]. This epidemic is multifactorial in origin. It is often accompanied by hyperuricemia. Hyperuricemia is defined as a level of serum uric acid greater than or equal to $70 \mathrm{mg} / \mathrm{l}(420 \mu \mathrm{mol} / \mathrm{l})$ in $\mathrm{man}$ and $60 \mathrm{mg} / \mathrm{l}(360$ $\mu \mathrm{mol} / \mathrm{l}$ ) in women. It is a factor of occurrence or progression of chronic kidney disease by several studies. However, it is difficult to know whether hyperuricemia is a risk factor for the development or progression of the CKD. Hyperuricemia may be a consequence of decreasing of glomerular filtration rate (GFR), reflecting tissue hypoxia or cell lysis associated with renal disease [6] [7]. Also the frequent association of hyperuricemia with other risk factors such as high blood pressure, diabetes and cardiovascular diseases makes difficult its causal link between development and progression of the CKD. Recent experimental and epidemiological data correlate the association of hyperuricemia with CKD, arterial hypertension and cardiovascular diseases, thus raising the question of the usefulness of therapeutics in reducing of hyperuricemia for prevention of renal disease [8]. A recent study in Australia of 21.475 healthy volunteers followed prospectively for 7 years suggests that hyperuricemia is an independent risk factor for the onset of chronic kidney disease [9]. However, there are few studies on the association of hyperuricemia with the development or progression of renal disease in Africa. This work was initiated for the first time in Chad to study the impact of hyperuricemia on the epidemiological, clinical and paraclinic profile of patients with chronic renal insufficiency.

\section{Materials and Methods}

The study was conducted in the nephrology-hemodialysis unit and cardiology service of General Hospital (GHNR) of National Reference in N'Djamena. This is a descriptive and analytical study conducted at hemodialysis unit and cardiology 
service of General Hospital of National reference of N'Djamena (Chad) from $1^{\text {st }}$ January to $1^{\text {st }}$ October 2013 (10 months). We included all chronic kidney disease patients hospitalized in hemodialysis unit and cardiology service who presented associated hyperuricemia. The information was collected on fact sheets from patients and their families. We have obtained the informed consent of patients. Socio-demographic characteristics of the patients (age, sex, level of education, profession, provenance); Anthropometric measurements (weight, height, waist circumference, body mass index); Eating habits (smoking, alcoholism, excessive consumption of meat or sugary drinks); Clinical data (medical history, duration of development, reason for consultation, clinical signs on physical examination); biologic data (hemogram, serum creatinine, azotemia, uricemia, creatinine clearance, lipid balance, blood ionogram, hematuria, proteinuria (positive if $>300 \mathrm{mg}$ ), the management and finally the prognosis of the patients were analyzed.

- Hyperuricemia was defined as a level of serum uric acid greater than or equal to $70 \mathrm{mg} / \mathrm{l}(420 \mu \mathrm{mol} / \mathrm{l})$ in man and $60 \mathrm{mg} / \mathrm{l}(360 \mu \mathrm{mol} / \mathrm{l})$ in women.

- The classification of nutritional status according to the WHO and the International Obesity Task Force (1998) was used:

o Undernutrition is a body mass index (BMI) of less than $18.5 \mathrm{~kg} / \mathrm{m}^{2}$

o BMI between 18.5 and $24.9 \mathrm{~kg} / \mathrm{m}^{2}$ is considered normal in an adult;

o BMI between $25-29.9 \mathrm{~kg} / \mathrm{m}^{2}$, it is overweight (overweight);

o Moderate obesity was defined as a BMI of $30-34.9 \mathrm{~kg} / \mathrm{m}^{2}$;

o Severe obesity was defined as a BMI of $35-39.9 \mathrm{~kg} / \mathrm{m}^{2}$

o Morbid obesity was defined as a BMI $>40 \mathrm{~kg} / \mathrm{m}^{2}$.

- Arterial hypertension: elevation of blood pressure > 140 and/or $90 \mathrm{mmHg}$.

- Smoking was defined by the use of smoking tobacco during the last 30 days prior to this consultation.

- Only regular consumption of alcohol, sugary drinks and meat was taken into account without being quantified: yes versus no.

The data obtained were analyzed using Excel and SPSS (Statistical Package for Social Sciences 18.0).

\section{Results}

\section{1) Epidemiology}

During our study period, 712 CKD patients were hospitalized and among them, there were 108 patients who were included in the study and who had hyperuricemia as a prevalence of $15.20 \%$. Concerning the profession there were 45 traders (41.6\%), 27 housewives (25.7\%), 18 civil servants (16.6\%), 9 drivers (8.3\%) and 9 soldiers (8.3\%) as shown in Table 1. The mean age was 35.5 years and the extremes were 29 to 85 years. The age group $40-60$ years represented $54.6 \%$ of the cases and the sex ratio was $3 / 1$. All patients consumed meat per day; 100 patients (92.6\%) were taking sweet drinks; $76(70.3 \%)$ took at least 2 cup of alcohol per day; 32 patients smoked tobacco (29.6\%).

2) Clinic and paraclinic:

Regarding risk factors there were 53 patients who were hypertensive (49.1\%), 
14 patients who were diabetic and hypertensive (12.9\%) and 8 diabetic patients (7.4\%). It was noted that 33 patients had no risk factors (30.6). Regarding BMI, the mean BMI was $29.5 \pm 12.4$, there were 39 overweight patients (36.1\%), 28 patients (25.9\%) with moderate obesity, 19 with severe obesity(17.6\%), 8 patients (7.4\%) with morbid obesity, 9 normal BMI patients (8.4\%) and 5 moderate undernutrition patients (4.6\%). For the waist circumference there were 68 (62.9\%) patients whose measurement was greater than $102 \mathrm{~cm}$ and 38 patients between 88 and $102 \mathrm{~cm}(35.2 \%)$. It was noted that 2 patients had waist circumference less than $88 \mathrm{~cm}$ (1.8\%). The mean uric acid level was $65.4 \pm 12.8 \mathrm{mg} / \mathrm{l}$. It was noted that 64 patients (94\%) had uric acid levels up to $90 \mathrm{mg} / \mathrm{l}$ and 44 patients had hyperuricemia between 70 and $90 \mathrm{mg} / \mathrm{l}$. The distribution of our patients according to the stage of chronic renal insufficiency was summarized in Table 2. Moderate chronic renal insufficiency (CKD 3) was observed in $43.5 \%$ of cases. There were $5.6 \%$ of patients who were at the terminal stage. Severe anemia with hemoglobin less than $8 \mathrm{~g} / \mathrm{dl}$ was noted in $69.5 \%$ of patients. Ninety-six patients, $88.9 \%(\mathrm{~N}=96)$, had serum creatinine levels greater than $14 \mathrm{mg} / \mathrm{l}$ and $25 \%$ had more than $80 \mathrm{mg} / \mathrm{l}$. Univariate analysis showed that there is a statistically positive relationship between hyperuricemia and age of patients (40 to 60 years and 61 to 80 years with respectively $p=0.0000$ and $p=0.003$ ), high blood pressure and occupation (trader and housewife with $\mathrm{p}=0.0005$ ). Treatment consisted of prescribing Allopurinol in $83.3 \%$ of patients. In $88.9 \%$ the trend was favorable.

\section{Discussion}

During our study period, 108 hyperuricemic patients were included. The total

Table 1. Distribution of patients according to occupation.

\begin{tabular}{ccccccc}
\hline \multirow{2}{*}{ Occupation } & $\mathrm{n}$ & $\%$ & \multicolumn{3}{c}{ Uricemia $(\mathrm{mg} / \mathrm{l})$} & $\mathrm{p}$ \\
\cline { 5 - 6 } & & & & $<70$ & $70-90$ & $>90$ \\
Driver & 9 & 8.3 & 1 & 3 & 5 & 0.839 \\
Trader & 45 & 41.7 & 4 & 6 & 35 & 0.0005 \\
Fonctionnaire & 18 & 16.7 & 0 & 6 & 12 & 0.448 \\
Housewife & 27 & 25.0 & 2 & 15 & 10 & 0.0005 \\
Military & 9 & 8.3 & 0 & 7 & 2 & 0.015 \\
Total & 108 & 100 & 7 & 37 & 64 & \\
\hline
\end{tabular}

Table 2. Distribution of patients according to GFR.

\begin{tabular}{ccc}
\hline GFR $(\mathrm{ml} / \mathrm{mn})$ & Patients & Percentage \\
\hline 90 & 12 & 11.1 \\
$60-89$ & 9 & 08.3 \\
$\mathbf{3 0}-\mathbf{5 9}$ & 47 & 43.5 \\
$15-29$ & 34 & 31.5 \\
$<15$ & 6 & 05.6 \\
Total & 108 & 100.0 \\
\hline
\end{tabular}


population was 712 patients, as a prevalence of hyperuricemia of $15.20 \%$. It was superior to other studies carried out in the Indian population of the Amazon region of Brazil with 5.6\% [12], and 5.1\% in healthy Spanish male subjects, a study conducted in Valencia (54), but lower than results in Russian and hypertensive patients' study (31\%) [10] [11] [13].

The most affected age group was 50 - 60 years (54.6\%) with a male predominance ( quadruple multivariate risk of hyperuricemia [14]. These results confirm the data from the Framingham study showing higher values of uric acid in men compared to women [15]. Estrogens in women have a depressing effect on urates [16]. The male sex aged over 55 years and the female sex aged over 65 were cited as cardiovascular risk factors [17]. Associated with hyperuricemia, age increases the likelihood of stroke in both sexes, and myocardial infarction in men [18].

Of the 108 patients, $70.3 \%$ consumed alcohol. Our result was superior to that of LON-GO et al., who reported $20 \%$ excess univariate risk of hyperuricemia due to alcoholism [14]. The abuse of alcohol consumption is the basis of gout attacks [19] [20] [21]. Obesity has been identified as a multivariate risk factor for hyperuricemia. Obesity, an independent variable, confers a double risk of hyperuricemia to Congolese hypertensive patients [14]. Our result is lower than that of Jean et al. who reported 30\% excess risk of hyperuricemia in Congolese Kinshasa patients linked to obesity [14]. Longo-Mbenza et al. found a positive and very significant correlation between body weight and uric acid in a population where hyperuricemia was isolated as a significant risk factor for stroke and coronary heart disease [18] The role of insulin resistance in the pathogenesis of cardiovascular diseases in African black, as emphasized by Longo-Mbenza [22] [23], will be the challenge to be overcome by African researchers in eradicating the epidemic of chronic non communicable diseases. Its reflection blood biology is hyperuricemia and hypertriglyceridemia as suggested by the work of Clausen [24].

In our study, 32 hyperuricemic patients were active smokers, as $29.6 \%$. Our result was lower than that of Jean et al., who reported $67.4 \%$ of patients with hyperuricemia among tobacco users [14]. Smokers have a univariate risk of hyperuricemia twice as high as their non-smoking colleagues. Longo-Mbenza et al. had already demonstrated a significant association between cigarette smoking and high levels of uric acid [18]. Other studies in the literature confirm this significant relationship between smoking and hyperuricemia [25] [26]. Majority of our patients had a high waist circumference. High waist circumference values define insulin resistance. This positive and significant relationship between waist circumference and hyperuricemia confirms data from the literature that considers hyperuricemia as a component of insulin resistance/metabolic syndrome [18] [19] [24] [25] [26] [27].

In our study, 67 patients (62\%) were hypertensive with statistically positive relationship between hyperuricemia and hypertension. The positive and significant relationship between hyperuricemia and blood pressure has been observed 
in Congolese patients in Kinshasa [18] and in other literature [10] [11] [19] [25] [28] [29]. Interpret as blood pressure may be a consequence of hyperuricemia. The present study considers the implications of the discovery of hyperuricemia in patients with essential arterial hypertension [29]. Indeed, no patient had a gout attack despite hyperuricemia [18]. But some attacks of gout settle with a normal blood level of uric acid [30]. This prevalence of asymptomatic hyperuricemia has already been estimated to be very high in Polynesian women [31].

Some studies have shown that hyperuricemia is associated with a high risk of kidney disease incidence [32] [33], but this association may be confused by factors not included in these previous studies [34]. Hypertension was considered a confounding factor. However, studies have shown that hyperuricemia is an independent risk factor for hypertension [35]. In our study, normotensive patients with hyperuricemia had developed renal disease. Our result is similar to that of Bellomo et al., which reported that each increase of $10 \mathrm{mg} / \mathrm{l}(59 \mu \mathrm{mol} / \mathrm{l})$ was associated with $23 \%$ risk of decreased GFR greater than $2 \mathrm{ml} / \mathrm{min} /$ year (after adjustment of confounding factors) in healthy normotensive adults [12]. A randomized clinical trial in hyperuricemic adolescents with hypertension (the decrease in uricemia under allopurinol was related to a decrease in blood pressure) changed the classic design where the cardiovascular drop-risk association in some studies was due to 1 Gout belongs to the metabolic syndrome [36].

The decrease in GFR was considered to be a key confounding variable, as serum uric acid elevation is generally associated with transport defects in nephrons when renal function deteriorates [37]. This study did not record the pre-existing nephropathy in patients who may explain the occurrence of hyperuricemia. Also in a study including 117 non diabetic patients with CKD (mean GFR $64 \pm 39$ $\mathrm{ml} / \mathrm{min} / 1.73 \mathrm{~m}^{2}$ ) with doubling of creatinine or terminal renal failure requiring dialysis did not have a higher uric acid level than other patients [38]. Similarly, in a retrospective study analyzing 223 patients with Ig A nephropathy, hyperuricemia was observed in association with an increased risk of progression of the chronic kidney disease [39] but was no longer statistically significant after adjustment for Confounding factors. Nevertheless, uric acid may have an independent role in the development of tubulo-interstitial lesions and contribute to inflammation in the renal parenchyma observed in these patients [40] as in other chronic glomerulopathies [41]. Thus, although hyperuricemia may be a consequence of a pre-existing kidney disease, these results show the involvement of uric acid in renal diseases.

In our study, 65 patients, as $59.7 \%$, did not have a pathological history that could explain the occurrence of a kidney disease other than the hyperuricemia they presented. But compared with the large international cohorts in this field, our study was limited by the weakness of the sample. Thus, in a study involving 21,475 healthy volunteers in Australia followed on average for 7 years, the risk of developing a CKD 3 stage was $26 \%$ higher in individuals with slightly higher than normal uric acid levels $(416-526 \mu \mathrm{mol} / \mathrm{l}$ or 70 to $90 \mathrm{mg} / \mathrm{l})$. This result would prove the implication of uric acid in renal disease. Thus, an improvement 
in renal function under allopurinol $100 \mathrm{mg} / \mathrm{d}$ in a randomized study involving 113 patients was observed [42].

\section{Conclusion}

Hyperuricemia has long been associated with chronic kidney disease. In our study, 108 hyperuricemic patients suffering from chronic kidney disease had no other factors that could explain the occurrence of their disease. It is common in the majority of hypertensive patients. Factors such as male sex, age, obesity, smoking, abuse of alcohol and sugary drinks, waist circumference, blood glucose and blood pressure are risk factors for hyperuricemia. A statistically significant relationship has been found between hyperuricemia, hypertension and the profession. The implication of hyperuricemia in renal disease is proved by several recent studies. However, large-scale randomized studies seem necessary to determine whether the reduction in uric acid has a beneficial effect on the prevention or treatment of this condition.

\section{References}

[1] Kenyan, G., Lameire, N., Barsoum, R., Eckardt, K.U., Levin, A., Levin, N., Locatelli, F., MacLeod, A., Vanholder, R., Walker, R. and Wang, H. (2004) The Burden of Kidney Disease. Improving Global Outcomes. Kidney International, 66, 1310-1314. https://doi.org/10.1111/j.1523-1755.2004.00894.x

[2] Who-Burden of Disease Project. In WHO (ed): Menu.cfm?path=evidence.burden\& language. WHO, 2006. http://www.3.whoint/whosis

[3] Arogundade, F.A. and Barsoum, R.S. (2008) CKD Prevention in Sub-Saharan Africa: A Call for Governmental, Nongovernmental, and Community Support. American Journal of Kidney Diseases, 51, 515-523. https://doi.org/10.1053/j.ajkd.2007.12.006

[4] Abegunde, D.O., Mathers, C.D., Adam, T., Ortegon, M. and Strong, K. (2007) The Burden and Costs of Chronic Diseases in Low-Income and Middle-Income Countries. The Lancet, 370, 1929-1938. https://doi.org/10.1016/S0140-6736(07)61696-1

[5] Sumaili, E.K., Krzesinski, J.M., Zinga, C.V., Cohen, E.P., Delanaye, P., Munyanga, S.M. and Nseka, N.M. (2009) Prevalence of Chronic Kidney Disease in Kinshasa: Results of a Pilot Study from the Democratic Republic of Congo. Nephrology Dialysis Transplantation, 24, 117-122. https://doi.org/10.1093/ndt/gfn469

[6] Elsayed, N.M., Nakashima, J.M. and Postlethwait, E.M. (1993) Measurement of Uricacid as a Marker of Oxygen Tension in the Lung. Archives of Biochemistry and Biophysics, 302, 228-232. https://doi.org/10.1006/abbi.1993.1204

[7] Cannon, P.J., Stason, W.B. and Demartini, F.E. (1966) Hyperuricemia in Primary and Renal Hypertension. The New England Journal of Medicine, 275, 457-464. https://doi.org/10.1056/NEJM196609012750902

[8] Hassan, I. and Gilbert, D. (2011) Acide urique et fonction rénale. Revue du Rhumatisme, 78, S134-S141. https://doi.org/10.1016/S1169-8330(11)70026-6

[9] Obermayr, R.P., Temml, C. and Gutjahr, G. (2008) Elevated Uric Acid Increases the Risk for Kidney Disease. Journal of the American Society of Nephrology, 19, 24072413. https://doi.org/10.1681/ASN.2008010080

[10] Dussol, B. (2011) Différents stades de l'insuffisance rénale chronique; Recommandations. IMMBIO-2445; No. of Pages 5. 
[11] Krummel, T., Bazin, D., Faller, L. and Hannedouche, T. (2011) Diagnostic, facteurs de risque et traitement de l'insuffisance rénale chronique de l'adulte. Néphrologie, 18-060-A-05, Elsevier Masson SAS, Paris.

[12] Park, J.T., Kim, D.K., Chang, T.I., et al. (2009) Uric Acid Is Associated with the Rate of Residual Renal Function Decline in Peritoneal Dialysis Patients. Nephrology Dialysis Transplantation, 24, 3520-3525.

[13] Donskov, A.S., Balkarov, I.M., Golub, G.V. and Anikina, S.A. (2002) Clinical Implication of the Body Mass and Waist/Thigh Indices in Hypertensive Patients: Correlations with Blood Uric Acid Levels. Klinicheskaia Meditsina, 80, 31-34.

[14] Jean de Dieu Lutonadio (2003) Hyperuricémie, groupe sanguine B et autres facteurs de risque cardiovasculaire à Kinshasa,Université Simon Kimbangu, th.Med.

[15] Brand, F.N., McGee, D.L., Kannel, W.B. and Castelli, W.P. (1985) Hyperuricemia as a Risk Factor of Coronary Heart Disease: The Framingham Study. American Journal of Epidemiology, 121, 11-18

[16] Mikkelsen, W.M., Dodge, H.J. and Valdenburg, H. (1965) The Distribution of Serum Uric Acid Values in a Population Unselected as to Gout or Hyperuricemia: Tecumseh, Michigan, 1959-1960. American Journal of Medicine, 39, 242-251. https://doi.org/10.1016/0002-9343(65)90048-3

[17] Nkoy, B.J. (2002) Facteur de risque cardio-vasculaire, maladie cardio-vasculaire et gradient social en milieu professionnel (Cas de la SNEL). Ms Degree Thesis, Kinshasa University, Kinshasa.

[18] Longo-Mbenza, B., Lukokiluila, E., Phanzu, M. and Kintoki, V.E. (1999) Is Hyperuricemia a Risk Factor of Stroke and Coronary Heart Disease. International Journal of Cardiology, 71, 17-22. https://doi.org/10.1016/S0167-5273(99)00097-2

[19] Wortmann, R.L. (2002) Gout and Hyperuricemia. Current Opinion in Rheumatology, 14, 281- 286. https://doi.org/10.1097/00002281-200205000-00015

[20] Faller, J. and Fox, I.H. (1982) Ethanol-Induced Hyperuricemia. The New England Journal of Medicine, 307, 1598-1602. https://doi.org/10.1056/NEJM198212233072602

[21] Cowie, M.R. (1997) Alcohol and the Heart. British Journal of Hospital Medicine, 57, 457-460.

[22] Bieleli, E., Moswa, J.L., Ditu, M., Kandjingu, K. and Mulumba, M. (2000) Prevalence du diabète sucré au sein de la population de Kinshasa. Congo Médical, 2, 1058-1061.

[23] Longo-Mbenza, B. (1995) Diabète sucré et maladies cardiovasculaires. Tropical Cardiology, 21, 37-44.

[24] Clausen, J.O., Borsch-Johnsen, K., Ibsen, H. and Pedersen, O. (1998) Analysis of the Relationship between Fasting Serum Uric Acid and the Insulin Sensitivity Index in a Population-Based Sample of 380 Young Healthy Caucasians. Journal of Endocrinology, 138, 63-69.

[25] Imazu, M., Yamamoto, H., Toyofuku, M., Sumii, K., Okobo, M., Egusa, G., et al. (2001) Hyperinsulinemia for the Development of Hypertension: Data from the Hawaii-Los Angeles-Hiroshima Study. Hypertension Research, 24, 536-551.

[26] Rathmann, W., Funkhouser, E., Dyer, A.R. and Roseman, J.M. (1998) Relations of Hyperuricemia with the Various Components of the Insulin Resistance Syndrome in Young Black and White Adults: The CARDIA Study. Coronary Artery Risk Development in Young Adults. Annals of Epidemiology, 8, 250-261. https://doi.org/10.1016/S1047-2797(97)00204-4

[27] Rattarasarn, C., Leelawattana, R., Soonthornpun, S., Setasuban, W., Thamprasit, A. and Lim, A. (2003) Regional Abdominal fat Distribution in Learn and Obese Thai 
Type 2 Diabetic Women, Relationships with Insulin Sensitivity and Cardiovascular Risk Factors. Metabolism, 52, 1444-1447. https://doi.org/10.1016/S0026-0495(03)00257-9

[28] Cicoira, M., Zanolla, L., Rossi, A., Golia, G., Franceschini, L. and Brighetti, G. (2002) Elevated Serum Uric Acid Levels Are Associated with Diastolic Dysfunction in Patients with Dilated Cardiomyopathy. American Heart Journal, 143, 1107-1111. https://doi.org/10.1067/mhj.2002.122122

[29] Richard, J., Duk-Hee, K., Daniel, F., Salah, K., John, K., et al. (2003) Is There a Pathogen Iticrole for Uric Acid in Hypertension and Cardiovascular and Renal Disease. Hypertension, 41, 1183. https://doi.org/10.1161/01.HYP.0000069700.62727.C5

[30] Mbuyamba, K.J.R., Lijnen, P., Fagard, R. and Amery, A. (1986) Intraerythrocyte $\mathrm{Na}+$ Concentration in Black Families with and without Hypertension. Methods and Findings in Experimental and Clinical Pharmacology, 8, 437-442.

[31] Simmonds, H.A. (1994) Polynesian Women Are Also at Risk for Hyperuricemia and Gout Because of a Genetic Defect in Renal Urate Handling. British Journal of Rheumatology, 33, 932-937. https://doi.org/10.1093/rheumatology/33.10.932

[32] Domrongkitchaiporn, S., Sritara, P., Kitiyakara, C., Stitchantrakul, W., Krittaphol, V., Lolekha, P., Cheepudomwit, S., et al. (2005) Risk Factors for Development of Decreased Kidney Function in a Southeast Asian Population: A 12-Year Cohort Study. Journal of the American Society of Nephrology, 16, 791-799.

https://doi.org/10.1681/ASN.2004030208

[33] Obermayr, R.P., Temml, C., Knechtelsdorfer, M., Gutjahr, G., Kletzmayr, J., Heiss, S., et al. (2008) Predictors of New-Onset Decline in Kidney Function in a General Middle-European Population. Nephrology Dialysis Transplantation, 23, 1265-1273. https://doi.org/10.1093/ndt/gfm790

[34] Szklo, M. and Nieto, F.J. (2007) Epidemiology beyond the Basics. 2nd Edition, Jones and Bartlett Publishers, Boston, 154-187.

[35] Heinig, M. and Johnson, R.J. (2006) Role of Uric Acid in Hypertension, Renal Disease, and Metabolic Syndrome. Cleveland Clinic Journal of Medicine, 73, 10591064.

[36] Mazzali, M., kanbay, M. and Segal, M.S. (2010) Uric Acid and Hypertension: Cause or Effect? Current Rheumatology Reports, 12, 108-117. https://doi.org/10.1007/s11926-010-0094-1

[37] Schoolwerth, D.A. and Sica, A.C. (2004) Handling of Organic Anions and Cations: Excretion of Uric Acid. In: Brenner, B.M., Ed., The Kidney, 7th Edition, WB Saunders, Philadelphia, 645-649.

[38] Perlstein, T.S., Hopkins, G., et al. (2004) Uric Acid and the State of the Intrarenal Renin-Angiotensin System in Humans. Kidney International, 66, 1465-1470. https://doi.org/10.1111/j.1523-1755.2004.00909.x

[39] Bellomo, G., Venanzi, S. and Verdura, C. (2010) Association of Uric Acid with Changes in Kidney Function in Healthy Normotensive Individuals. American Journal of Kidney Diseases, 56, 264-272. https://doi.org/10.1053/j.ajkd.2010.01.019

[40] Hovind, P., Rossing, P. and Tarnow, L. (2009) Serum Uric Acid as a Predictor for Development of Diabetic Nephropathy in Type 1 Diabetes: An Inception Cohort Study. Diabetes, 58, 1668-1671. https://doi.org/10.2337/db09-0014

[41] Ficociello, L.H., Rosolowsky, E.T. and Niewczas, M.A. (2010) High-Normal Serum Uric Acid Increases Risk of Early Progressive Renal Function Loss in Type 1 Diabetes: Results of a 6-Year Follow-Up. Diabetes Care, 33, 1337-1343. https://doi.org/10.2337/dc10-0227 
[42] Siu, K.T. and Leung, M.K. (2006) Tong Use of Allopurinol in Slowing the Progression of Renal Disease through Its Ability to Lower Serum Uric Acid Level. American Journal of Kidney Diseases, 47, 51-59.

https://doi.org/10.1053/j.ajkd.2005.10.006

\section{Abbreviations}

GFR: glomerular filtration rate;

CKD: chronic kidney disease;

BMI: body mass index.

\section{Scientific Research Publishing}

Submit or recommend next manuscript to SCIRP and we will provide best service for you:

Accepting pre-submission inquiries through Email, Facebook, LinkedIn, Twitter, etc. A wide selection of journals (inclusive of 9 subjects, more than 200 journals) Providing 24-hour high-quality service User-friendly online submission system Fair and swift peer-review system Efficient typesetting and proofreading procedure Display of the result of downloads and visits, as well as the number of cited articles Maximum dissemination of your research work

Submit your manuscript at: http://papersubmission.scirp.org/ Or contact ojneph@scirp.org 